\title{
Vorticella and Colacium as epibionts of copepods in Pasig river, Philippines
}

\author{
Pia S. Corre ${ }^{1 *}$, Mary Rose Clarence S. Abadilla ${ }^{2}$, Mark Nathaniel L. Arnaldo ${ }^{2}$, Marianne Therese S. \\ Irlanda $^{2}$, Andrea Czarina P. Mariano ${ }^{2}$, Irineo J. Dogma, Jr. ${ }^{1}$, and Rey Donne S. Papa ${ }^{1,2 ~ \& 3}$
}

\begin{abstract}
The chitinous exoskeleton of copepods serves as a scaffold for microepibionts such as protozoa. Although copepods are highly cosmopolitan, their associated epibionts in the tropics are poorly known. This study presents the first account in the Philippines of the ciliate Vorticella on calanoid copepod Arctodiaptomus dorsalis and both Vorticella and the euglenoid Colacium on the cyclopoid copepods Thermocyclops crassus and Mesocyclops microlasius in the Pasig River. Infestation, however, was low at $0.83 \%$ (108 out of 13,039) observed copepods from four collection sites in January-May and JulyDecember 2018. Interestingly, Vorticella and Colacium were frequently observed in cyclopoid than on calanoid copepods, predominantly on the urosome, thorax, cephalosome of copepodites and adult stages of copepods. Colacium was also found attached on the antennules, swimming legs, caudal rami and setae. Prevalence of epibionts was site-related; Vorticella being more abundant in waters near Manila Bay (Site 1) where high salinity, conductivity and total dissolved solids were recorded while Colacium was found more near Laguna de Bay (Site 4). Both were abundantly present in September and absent in May, due to increased inflow of seawater from Manila Bay. Nevertheless, overall low infestation resulted in neither significant spatial nor temporal variation of epibiosis in Pasig River, probably due to heavy loadings of wastewater from nearby tributaries, noticeable algal blooms, detachment of epibionts by predations and changes in water chemistry.
\end{abstract}

Keywords: protozoa, zooplankton, epibiosis

\section{Introduction}

Protozoa are unicellular eukaryotic microorganisms found on or within other organisms, in decaying matter, soil and the aquatic environment (Kudo, 1939; Finlay \& Esteban, 1998) by predating on bacteria and fungi (Hausmann et al., 2003). They are observed readily in microscopy as epibionts on planktonic microcrustaceans, such as copepods. Global records, generally from temperate and subtropical countries, indicate that copepods' chitinous exoskeleton is a favored niche of several protozoa like peritrich ciliates Vorticella, Epistylis, Zoothamnium, Trichodina, Scyphidia and Rhabdostyla,

${ }^{1}$ The Graduate School, ${ }^{2}$ Department of Biological Sciences, ${ }^{3}$ Research Center of Natural and Applied Sciences, University of Santo Tomas, Manila, Philippines

*Corresponding email: rspapa@ust.edu.ph

Date Submitted: 16 November 2019

Date Accepted: 06 July 2020 suctorians Pelagacineta, Euphelota, Paracineta, Ellobiopsis, and Tokophyra, apostome Vampyrophyra and flagellate Colacium epibionts (Green \& Sheil, 2000; Burris \& Dam, 2014; Gregori et al., 2016; Walkusz \& Rolbiecki, 2007; RegaliSeleghim \& Godinho, 2004; Clamp et al., 2016; Chiavelli et al., 1993; Ohtsuka et al., 2004). Other host substrates include cladocerans, isopods, decapods and other macrocrustaceans (Fernandez-Leborans \& Tato-Porto, 2000). The density and preferred attachment sites of epibionts affect the mobility, reproduction and survival of the host (Regali-Seleghim \& Godinho, 2004). The paper by Taniguichi et al. (1999), to our knowledge, is the lone Philippine occurrence record of epibionts on copepods (harpacticoida, calanoids, cyclopoids), ostracods and cladocerans. It documents with scanning electron micrographs (SEM) the predominance of unidentified rodshaped bacteria, microalgae and protozoa on these microcrustaceans found in overlaying irrigation water in rice paddies.

Our study explores in-depth and for the first time the spatial and temporal epibiosis of two protozoa on copepods in 
Pasig River, a highly eutrophic and complex water system with a seasonal shifting bidirectional flow and mixing of freshwater and seawater coming from opposite ends. Pasig River (Luzon Is., Philippines) is a $27-\mathrm{km}$ water system with a serpentine route flowing westward from Laguna de Bay, through Metro Manila to Manila Bay, the outlet facing the West Philippine Sea (Fig. 1). Laguna de Bay itself is heavily eutrophic, and the quality of its water downstream in Pasig River to Manila Bay is impacted by added inputs from four major and forty-seven minor tributaries and by different domestic and industrial pollutants from urban Metro Manila (Cruz, 1997). In sum, water in Pasig River is environmentally complex physically, chemically and biologically (Petts, 1986). Water quality is a measure of pollution level, which affects the diversity and abundance of zooplankton (Dorak, 2013). Our study focuses on the frequency and distribution of protozoa Vorticella and Colacium as epibionts on the body of host copepods, and their occurrence in relation to the physico-chemical factors in Pasig River in 2018.

\section{Materials and Methods}

\section{Study sites}

Four sampling sites stretched eastward along the Pasig River were selected for the study (Fig. 1). Site 1 $\left(40^{\circ} 35^{\prime} 42.57^{\prime \prime} \mathrm{N} ; 1^{\circ} 0^{\circ} 57^{\prime} 48.16^{\prime \prime} \mathrm{E}\right)$ was situated at Tacoma Port Area, Manila near the mouth of the river where vessels load and discharge cargos of commerce. Site 2 (14035'18.83'N; $\left.121^{\circ} 00^{\prime} 46.74^{\prime \prime} E\right)$ was at Santa Ana Port, Manila near the junction of San Juan River. It was surrounded by residential and industrial complexes, as is the case at Site $3\left(14^{\circ} 33^{\prime} 43.9^{\prime \prime} \mathrm{N}\right.$; $\left.121^{\circ} 03^{\prime} 45.01^{\prime \prime} E\right)$ in Pineda, Pasig City near Marikina River. Site 4 (14032'03.92”N; $\left.121^{\circ} 06^{\prime} 16.74^{\prime \prime} \mathrm{E}\right)$ was the closest to Laguna de Bay and at the boundary of Rizal Province and Pasig City.

\section{Field sampling}

Samples were collected monthly from January to May 2018 to determine the spatial variations of the physico-chemical features across the river and the occurrence of epibionts on copepods. Sites with significant variation in terms of physicochemistry data and frequency of copepods with epibionts were selected for further analysis in July to December 2018. No sampling was done in June due to inclement weather.

Samples for plankton were obtained with a use of $90-\mu \mathrm{m}$ mesh plankton net. Collection was done in replicates. The collected samples were placed in $500 \mathrm{ml}$ containers and transported to the laboratory for further processing. Water quality parameters such as $\mathrm{pH}$, salinity, TDS, temperature, dissolved oxygen and conductivity were measured in-situ using ExStik DO600, ExStik EC500 and Hach HQ40d portable water

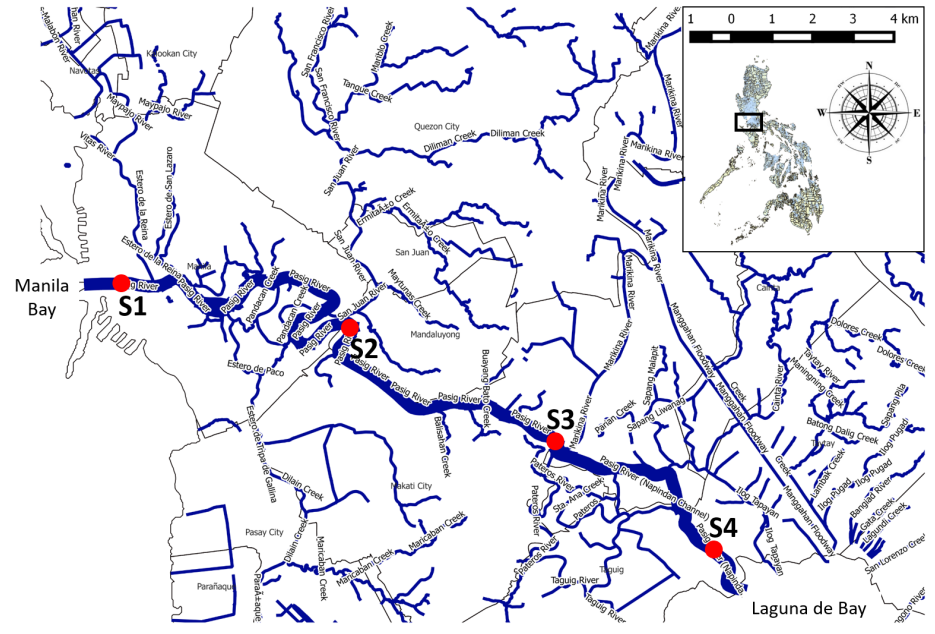

Figure 1. Location of the different sampling sites: S1-S4 represent sites along Pasig River

quality meters. DO was not recorded in Sites 1 and 3 due to authorities' restriction and site risk.

\section{Copepod identification and enumeration}

Distinctive morphological structures such as antennule length and segmentation were considered to differentiate copepods into orders Calanoida and Cyclopoida (Fernando, 2002) and thereafter, to species following Dussart \& Defaye (2011).

Copepods with and without protozoan as epibionts were sorted out in separate containers, and level of infestation was computed.

\section{Enumeration, examination and identification of copepod epibionts}

Infested live copepods were segregated and examined using Optika SZM-1 dissecting microscope and Olympus CX21 compound microscope for the numerical counts of epibionts and their attachment on the host body parts-antennule, cephalosome, segmented thorax and urosome, swimming legs, caudal rami and setae. Noted also were other morphological structures of epibionts: body shape and length, cilia and stalk. Identification of epibionts was based on the works of Foissner \& Berger (1996), Kudo, (1939) and Prescott (1951).

\section{Imaging}

Phase contrast micrographs were taken using B-350 Optika Microscope (Italy). Some infested specimens were fixed with $2 \%$ glutaraldehyde and dehydrated through graded series of ethanol and air dried prior to observation under Hitachi TableTop scanning electron microscope (Taniguchi et al., 1999). 


\section{Data analysis}

The significance of the percentage distribution of epibionts across the developmental stages of copepods was analyzed using one sample t-test and the frequency distribution of epibionts by Chi-square Goodness of Fit. Physico-chemistry data from January to May 2018 were analyzed using two-way ANOVA followed by Tukey HSD post hoc test. One-way ANOVA and independent sample t-test were used to analyze data recorded at Sites 1 and 4 from July to December 2018 using IBM SPSS Statistics version 20. Principal Component Analysis was used to evaluate the variation of the average values of the measured physico-chemical parameters from Pasig River over an 11-month period of sampling at Sites 1 and 4 through PAST 3.20. Figure showing the percent distribution of infested and non-infested copepods was generated using Sigma plot.

\section{Results}

\section{Copepods and their epibionts in the Pasig River}

Three species of copepods, namely: Arctodiaptomus dorsalis (Marsh, 1907) [Calanoida] and Thermocyclops crassus (Fischer, 1853) and Mesocyclops microlasius Kiefer, 1981 [both Cyclopoida] were collected from the Pasig River. Of the 13,039 copepods examined, only 108 copepods were infested (1 calanoid and 107 cyclopoids). One individual of $A$. dorsalis was seen infested by Vorticella while $T$. crassus and $M$. microlasius were found to be infested with Vorticella and Colacium. Among the infested cyclopoids, 27 had Vorticella, 57 had Colacium and 23 with both epibionts.

Vorticella (phylum Ciliophora) and Colacium (phylum Euglenozoa) were the only protozoan epibionts found on the copepods. Vorticella was observed abundantly on the urosome, thorax and cephalothorax in decreasing order both in copepodite and adult stages. In contrast, it was not found on the swimming legs and antennules (Fig. 3). Further, Vorticella was not equally distributed on the body of the copepod across CI $\left(\mathrm{c}^{2}(2, \mathrm{n}=20)\right.$ $=7.900, p=0.019)$, CII $\left(\mathrm{c}^{2}(2, \mathrm{n}=20)=7.900, p=0.019\right)$, CIII $\left(\mathrm{c}^{2}(2, \mathrm{n}=29)=8.345, p=0.015\right), \operatorname{CIV}\left(\mathrm{c}^{2}(2, \mathrm{n}=27)=21.440\right.$, $p<0.001), \mathrm{CV}\left(\mathrm{c}^{2}(2, \mathrm{n}=27)=8.667, p=0.013\right)$ and adult $\left(\mathrm{c}^{2}\right.$ $(2, \mathrm{n}=117)=86.000, p<0.001)$. For CI, Vorticella was found limited on the segmented thorax $(n=5)$ (Fig. 2). Infestation by Colacium was also observed in the same copepod body harboring Vorticella, but more abundantly on the cephalosome of adults and on the thorax for copepodites. In addition, it also attached on the antennule, legs, caudal rami and setae of copepods (Fig. 4). In contrast with that of Vorticella, Colacium distribution on the copepod body was found to be insignificant in $\mathrm{CI}\left(\mathrm{c}^{2}(4, \mathrm{n}=14)=4.571, p=0.334\right)$ and $\mathrm{CV}\left(\mathrm{c}^{2}(3, \mathrm{n}=44)=\right.$

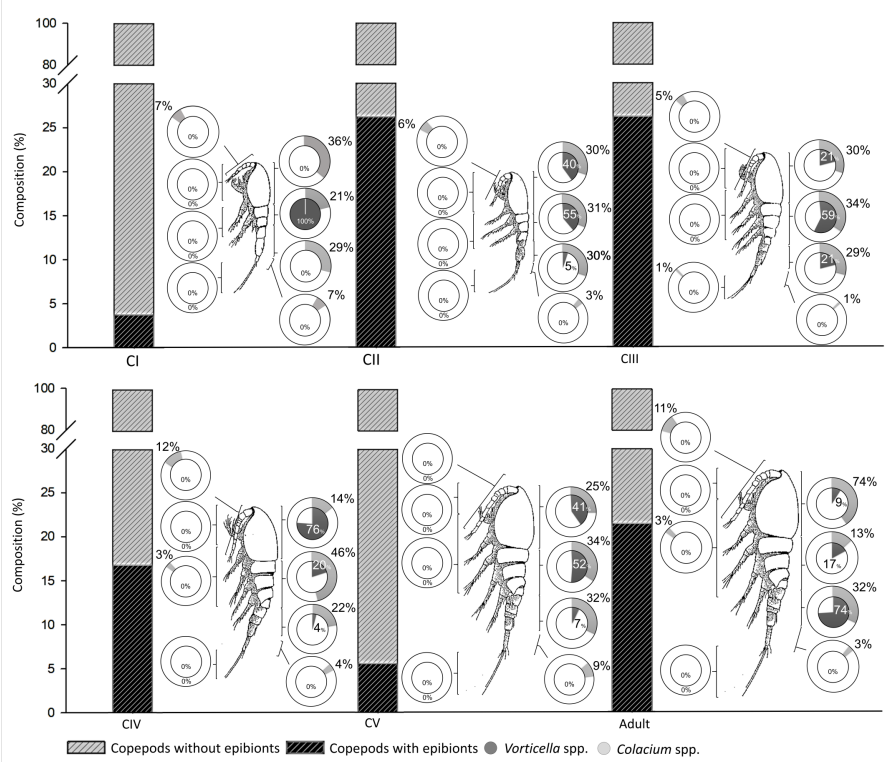

Figure 2. Percent distribution of Vorticella and Colacium across copepods' body segments in every copepodite and adult stages

6.727, $p=0.081)$ but significant in CII $\left(\mathrm{c}^{2}(4, \mathrm{n}=260)=\right.$ $103.346, p<0.001)$, CIII $\left(\mathrm{c}^{2}(5, \mathrm{n}=312)=241.654, p<0.001\right)$, CIV $\left(\mathrm{c}^{2}(5, \mathrm{n}=118)=89.356, p<0.001\right)$ and adult $\left(\mathrm{c}^{2}(5, \mathrm{n}=\right.$ $38)=27.053, p<0.001)$.

Epibionts were never seen in copepod nauplii. However, one sample t-test revealed that there was a significant difference on the percent distribution of epibionts across the copepodite and adult stages $(t(5)=4.11, p=0.009, \mathrm{~d}=1.67)$. Vorticella was mostly found on adults as compared to copepodite
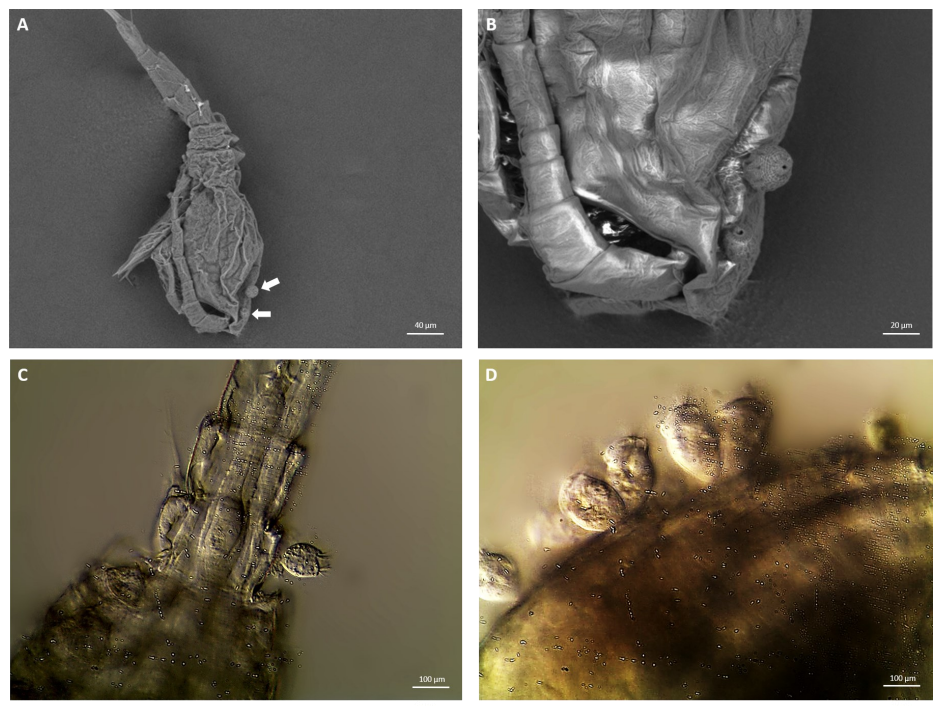

Figure 3. Vorticella (A) SEM of cyclopoid with Vorticella (B) magnification of Vorticella on cephalosome of cyclopoid (C) Phase contrast micrograph of Vorticella on urosome and on the (D) thorax segments 

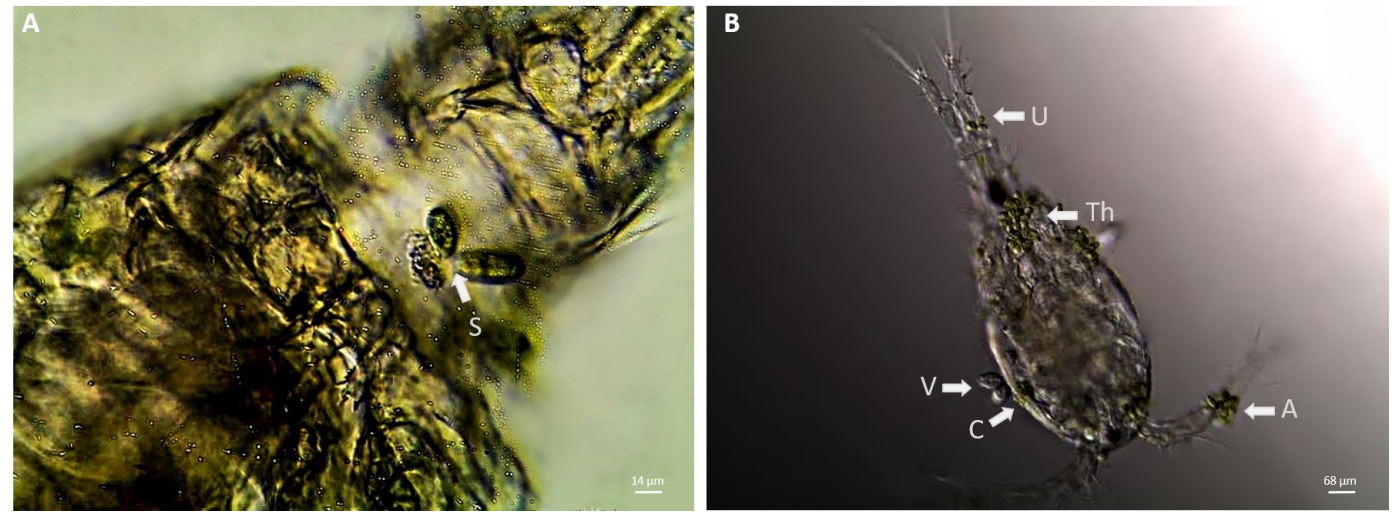

Figure 4. Colacium (A) Phase contrast micrograph of Colacium attached through its stalk on the urosome, (B) U-urosome, Th-thorax, C-cephalosome, A-antennule with V-Vorticella

copepods. In contrast, Colacium was mostly found on copepodite specifically on CII and III compared to adult (Fig. 2).

\section{Imaging}

Specimens of Vorticella in SEM micrographs had an inverted bell-shaped body (mean \pm standard error, SE), $95.87 \pm$ $7.00 \mu \mathrm{m}$ for length and $60.02 \pm 3.53 \mu \mathrm{m}$ for width. The peristome had a thick persitomial collar, circular central peristomial disc, transverse parallel pellicle striations (Fig. 5), prominent buccal ciliature in the peristomial region (Fig. 3) and erect outer ciliary row. Other details of the buccal region were not shown in the SEM; however, the stalk was seen in its contracted state. Live Vorticella was readily recognized when it responds to stimuli by the sequential shortening and lengthening of its contractile stalk. Euglenoid Colacium had a green ellipsoid body, $14.92 \pm 0.63 \mu \mathrm{m}$ long with rounded tip and 8.58 $\pm 0.31 \mu \mathrm{m}$ wide; within were numerous discoid chloroplasts. It occurred singly and had a short transparent stalk attached to but

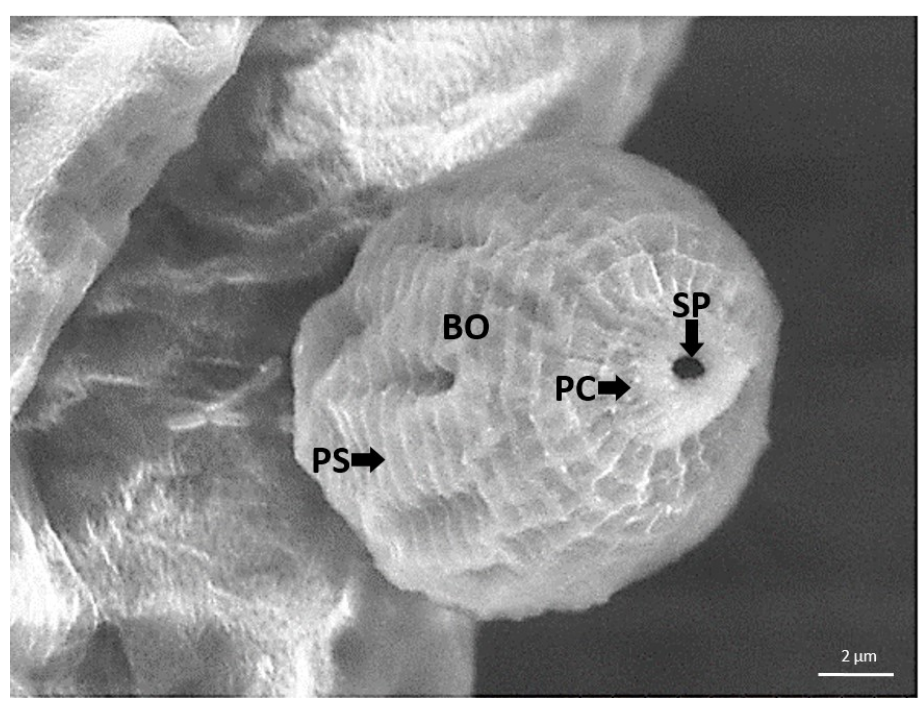

Figure 5. Vorticella showing captured parts under SEM with no apparent movement on the host. The flagellum was not seen using the SEM.

\section{Variation in epibionts across space and time}

The occurrence of epibionts on copepods showed no significant variation in terms of its spatial or temporal distribution due to its low prevalence. The highest prevalence of epibionts was 3\% in September 2018 (Fig. 6) and the mean prevalence for the whole sampling was $0.83 \%$.

There was a variation between the four sampling sites from January to May based on the physico-chemistry data: $\mathrm{pH}$ (F (12, $40)=129.812, p<0.001)$, salinity $(\mathrm{F}(12,40)=1340.136$, $p<0.001)$, conductivity $(\mathrm{F}(12,40)=237.747, p<0.001)$ and TDS $(\mathrm{F}(12,40)=502.117, p<0.001)$ from January to May. Post hoc Tukey HSD multiple comparison test revealed that Site 1 varied significantly in all sites in terms of TDS, conductivity and salinity. The mean values of TDS $(1318.28 \pm 285.95 \mathrm{mg} / \mathrm{L})$, conductivity $(1734.07 \pm 340.08 \mu \mathrm{S} / \mathrm{cm})$ and salinity $(998.93 \pm$ $201.29 \mathrm{ppm}$ ) were all highest in Site 1 as compared with the lower values in Site 4 for TDS $(331.95 \pm 5.51 \mathrm{mg} / \mathrm{L})$ and conductivity $(470.05 \pm 8.59 \mu \mathrm{S} / \mathrm{cm})$ and salinity $(273.19 \pm 23.82$ $\mathrm{ppm})$. The mean $\mathrm{pH}$ values across the four sampling months increased from Sites 1 to 4 ranging from 7.22 \pm 0.03-7.53 \pm 0.07 . The highest mean temperature value of $30 \pm 0.59{ }^{\circ} \mathrm{C}$ was recorded in Site 1 and lowest in Site 4 with $27.19 \pm 0.76^{\circ} \mathrm{C}$. DO concentration was higher in Site 4 as compared to Site 2 with mean values of $4.23 \pm 0.91 \mathrm{mg} / \mathrm{L}$ and $1.71 \pm 0.63 \mathrm{mg} / \mathrm{L}$, respectively (Fig. 7). Interestingly, copepods with epibionts were found in Site 1 and none in Site 4. This led to the selection of Sites 1 and 4 for further sampling in July to December 2018 . No further study was conducted in Sites 2 and 3 since copepods with epibionts only occurred once in Site 3 and none in Site 2. Salinity $(\mathrm{F}(5,30)=3.512, p=0.13)$, conductivity $(\mathrm{F}(5,30)$ $=91.018, p<0.001)$, TDS $(\mathrm{F}(5,30)=3.018, p=0.025)$ and temperature $(\mathrm{F}(5,30)=23.176, p<0.001)$ varied significantly 


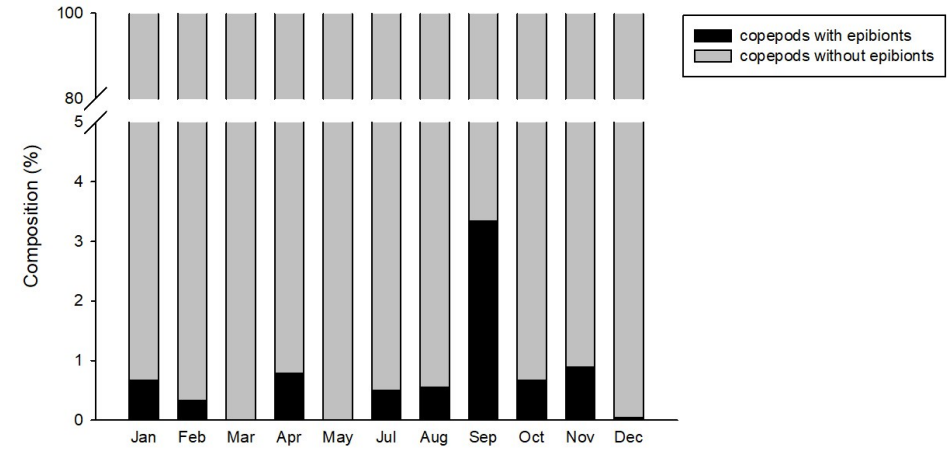

Figure 6. Percent composition of copepods with epibionts among the collected copepods in all selected sites in Pasig River.

from July to December. $\mathrm{pH}(\mathrm{t}(34)=-2.281, \mathrm{p}=0.029)$, salinity $(\mathrm{t}(34)=3.576, \mathrm{p}=0.001)$ and $\operatorname{TDS}(\mathrm{t}(34)=3.588, \mathrm{p}=0.001)$ varied significantly between Sites 1 and 4 .

PCA bi-plot revealed that average $\mathrm{pH}$, salinity, TDS and conductivity were the parameters contributing to the variation among Sites 1 and 4 during the 11 sampling months (Fig. 8). PC1 $(61.47 \%)$ and PC2 (24.799 \%), with eigenvalues >1, accounted for $86.27 \%$ of the total variance. Salinity, conductivity and TDS had high loadings on PC1 while $\mathrm{pH}$ was high on PC2 (Table 1).

There were 54, 3 and 51 copepods with epibionts recorded in Sites 1, 3, and 4, respectively. Only Vorticella were observed in Sites 1 and 3 and during the months of January, February and April. There were no recorded copepods with epibionts during the March and May collections. It was noticeable that phytoplankton such as cf. Melosira spp. and Microcystis spp. heavily dominated the river during March to April. It was also observed that copepods with epibionts were present in January to February 2018 during the outflow of water from Laguna de Bay and absent in March and May during the inflow of water from Manila Bay. Vorticella was recorded once in Site 1 in July and none in Sites 1 and 4 in August. Instead, Colacium spp.

Table 1. Factor loadings based on the principal component analysis for various water physico-chemical parameters

\begin{tabular}{lrr}
\hline \multicolumn{1}{c}{$\begin{array}{c}\text { Physico-chemical } \\
\text { parameter }\end{array}$} & PC1 & PC2 \\
\hline \% variance explained & 56.178 & 23.411 \\
$\mathrm{pH}$ & -0.168 & 0.690 \\
$\mathrm{Sal}(\mathrm{ppm})$ & 0.562 & 0.132 \\
Con $(\mu \mathrm{S} / \mathrm{cm})$ & 0.558 & 0.148 \\
TDS $(\mathrm{mg} / \mathrm{L})$ & 0.560 & 0.144 \\
Temp $\left({ }^{\circ} \mathrm{C}\right)$ & 0.178 & -0.681 \\
\hline
\end{tabular}
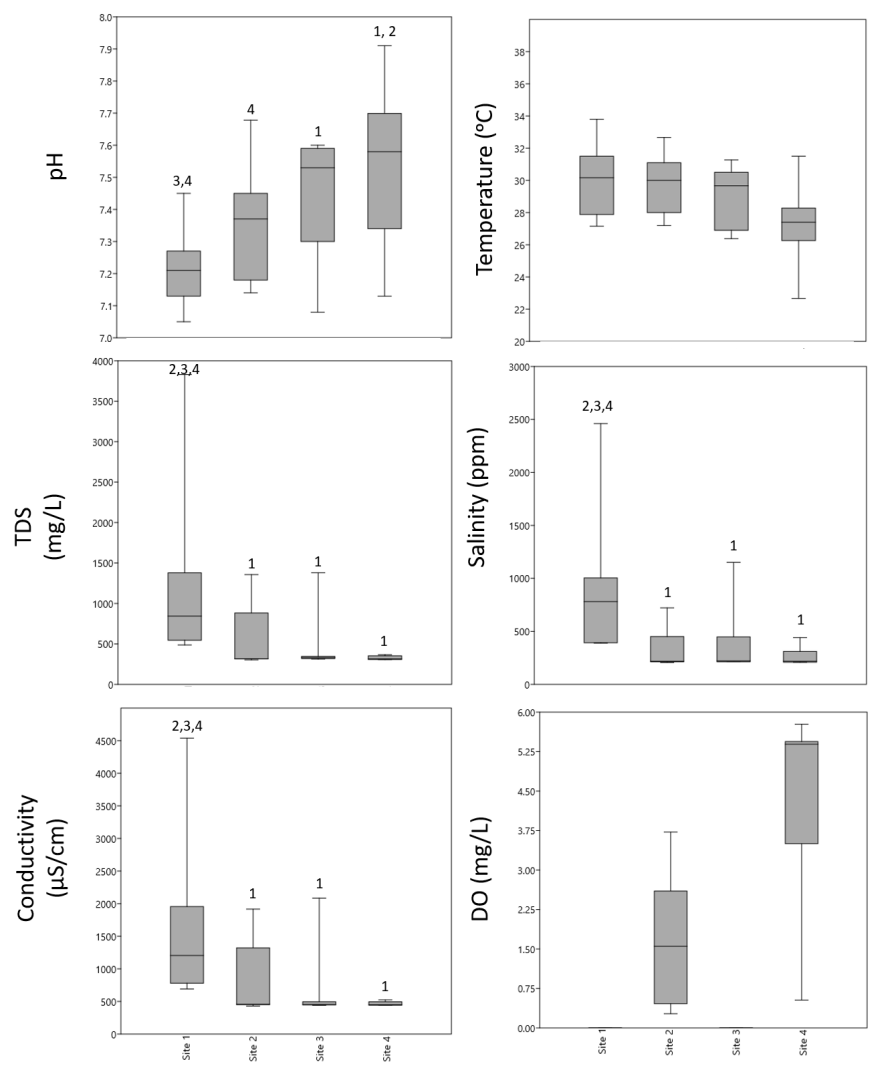

Figure 7. Box plot of physico-chemical parameters along the sampling sites from January to May 2018 *The numbers above bars indicate significant differences across the sites $(\mathrm{p}>0.05)$ based on Tukey HDS post hoc test

were frequently found as copepods' epibiont in July and the only epibiont in August and they occurred in both Sites 1 and 4. Both Vorticella and Colacium were observed abundantly in September and declined in October to December 2018.

\section{Discussion}

\section{Occurrence of epibionts on copepods}

Thermocyclops crassus, a species complex and widely distributed in Eurasia, Australia and the Americas, and Mesocyclops microlasius, endemic in the Philippines with records in Luzon Is. including Manila, Laguna and Rizal (Lopez et al., 2017) are herein recorded for the first time in Pasig River. In addition, Arctodiaptomus dorsalis, which is considered as an invasive species in Philippine lakes and was first recorded in Laguna de Bay (Papa et al., 2012), was also recorded in the river. The widespread distribution of these copepods may be the reason of their potential as substrate for epibiotic microorganisms.

The chitinous exoskeleton of copepods served as the 


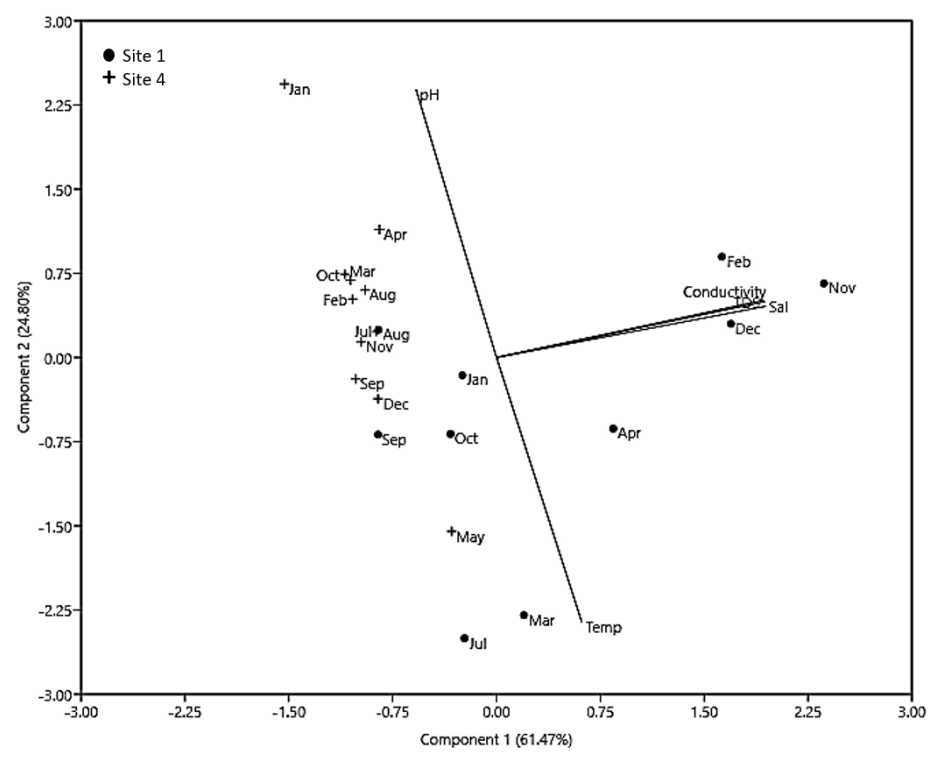

Figure 8. PCA bi-plot of the physico-chemical parameters of Sites 1 and 4 during the 11 month sampling in Pasig River

substrate for Vorticella and Colacium. Although both genera were observed as epibionts of cyclopoids, they interestingly showed similar points of attachment sites such as on the urosome, thorax and cephalosome and absence on some parts. Vorticella were found abundantly on the urosome since this segment lacks swimming legs that could interfere with their attachment. Also, food particles left by copepods may be directed towards the attached epibionts on the urosome and thorax regions. Attachment on the thorax and urosome may be favorable to both genera due to the lesser dragging force of water as compared when attached to the upper segment of the copepods. However, in the case of Colacium, the cephalosome was also a good site of attachment since it has greater surface area and could probably allow more epibionts to attach and easily establish a point of attachment considering that the host and the epibionts are motile. Other epibionts such as Paracineta sp. and Epistylis niagarae Kellicott, 1883 also had prosome and urosome as their points of attachment on Metridia longa (Lubbock, 1854), Paraeuchaeta norvegica (Boeck, 1872) and Mesocyclops aspericornis (Daday, 1906), respectively (Walkusz \& Rolbiecki, 2007; Rajabunizal \& Ramanibai, 2011). On the other hand, only Colacium were seen on the swimming legs, caudal rami and antennule of cyclopoids. This was also observed on Tigriopus fulvus (Fischer, 1860) but with another epibiont, Scyphidia (Pane et al., 2014). This was never the case of Vorticella in this study. This may be caused by the prominent elongated stalk that Vorticella possesses as compared to Colacium and Scyphidia. Its stalk also contracts and covers greater area. Due to the size and motility of Vorticella, swimming and feeding process of copepods may be hindered and may not withstand its movement. This suggests that attachment of epibionts vary and may depend on the size and habits of both the host and the epibionts.

Attachment of protozoa to copepods is facultative and may be associated with the mortality and molting of the host (Walkusz \& Rolbiecki, 2007). Both Vorticella and Colacium were found on copepodite and adult stages and never in naupliar stages which have a higher molting rate (Utz and Coat, 2005). Vorticella were mostly recognized on adult since molting occurred in copepodite stages. Contradicting to this case is Colacium wherein it was mostly observed in copepodite stages. This may be due to its capacity to attach until its substrate dies or dries up (Willey et al., 1990). Attachment of Colacium on adult copepods would further increase its size and result in an increase of its visibility to predators.

\section{Epibionts and their environment}

The occurrence of epibionts on copepods showed no correlation to the prevailing physico-chemical conditions of Pasig River due to their low prevalence. The $0.83 \%$ prevalence of epibionts on copepods computed in this study was even lower than the computed low prevalence value of 3.3\% of Epistylis sp. and Synedra sp. on calanoids and cyclopoids (López et al., 1998). Low occurrence of epibionts may suggest that other biotic or abiotic substrate might support Vorticella and Colacium, although attachment on live moving substrates could be beneficial. Other factors such as bacterial population and other water quality parameters such as depth and nutrient loadings which were not included in this study might be some factors that could further explain their presence and absence in each site and sampling months. It was reported that species of Vorticella can withstand acidic water with $\mathrm{pH}$ less than 3.0 (Packroff \& Woelfl, 2000), temperature ranging from 0-30 ${ }^{\circ} \mathrm{C}$ and dissolved oxygen ranging from 0-16 mg/L (Bick, 1972). Colacium was considered to be eurythermal and can thrive in an environment with $\mathrm{pH}$ value between 6 and 9 and dissolved oxygen levels between 3.6 and $10.4 \mathrm{mg} / \mathrm{L}$ (Ersanli \& Gonulol, 2003). The wide range of values suggests the adaptability of the epibionts in Pasig River. However, the duration and fluctuation of their exposure to such conditions may be the contributing factor that can trigger changes in its life phase and cause detachment.

Due to changing and stressful aquatic conditions, adhesion to a body surface that serves as a living support to epibiotic microorganisms becomes necessary for survival (Roszak \& Colwell, 1987). It was observed that Vorticella detached from copepods. Vorticella developed into a telotroch that swims and settles on a substrate by attaching its stalk and further develops 
into its adult stage. It tends to develop into a telotroch stage again and searches for another substrate where it could attach by growing over its stalk if the environment is unfavorable (Verma \& Jordan, 1995). In the case of Colacium, from its freeliving flagellated cell, it develops a stalk and adheres to a substrate until the substrate become unstable. It re-extrudes its flagellum and finds another substrate to attach on (Rosowski \& Kugrens, 1973). Both have vegetative stages that would require substrate for them to survive.

Because of their cystic, free-living stages and diminutive size, sampling and microscopy of protozoa hinder the study of their occurrence on copepods despite their abundance in the microbial community. Furthermore, observation of protozoa on live copepods was one of the challenges in this study. Nevertheless, this study presents the first account of the occurrence of Vorticella and Colacium as epibionts of copepods in Pasig River and in the Philippines. Both genera were found to attach frequently in the cephalosomal, thoracic and urosomal regions of copepods but only Colacium were found to attach on the antennule, swimming legs, caudal rami and setae. Their occurrence may not be explained by the environmental condition of the Pasig River but the effects of their exposure to the measured conditions may be a significant study. Moreover, this study contributes to the limited investigation of epibionts on copepods in the country and in the tropical regions.

\section{Acknowledgement}

We would like to acknowledge the valuable assistance and critical comments provided by Dr. Jonathan Carlo Briones, Dr. Ian Kendrich Fontanilla, Ms. Irisse Bianca de Jesus, Ms. Erica Silk dela Paz, Dr. Felicidad Ramirez and Dr. Susana Baldia during the conduct of this study.

\section{Literature Cited}

Bick, H, 1972. Cilated Protozoa. An Illustrated Guide to the Species as Biological Indicators in Freshwater Biology. World Health Organization, Geneva. 198 pp.

Burris, Z.P., Dam, H.G, 2014. Deleterious effects of the ciliate epibiont Zoothamnium sp. on fitness of the copepod Acartia tonsa. Journal of Plankton Research, 36 (3): 788-799. https://doi.org/10.1093/plankt/fbt137.

Chiavelli, D.A., E.L. Mills \& S.T. Threlkeld, 1993. Host preference, seasonality, and community interactions of zooplankton epibionts. Limnology and Oceanography, 38: 574-583. 10.4319/10.1993.38.3.0574.

Clamp, J.C., T. Chatterjee \& G. Fernandez-Leborans, 2016. Occurrence of Epistylis anastatica (Linnaeus, 1767)
(Ciliophora: Peritrichia) on Mesocyclops isabellae Dussart \& Fernando (Crustacea: Copepoda: Cyclopoida) in India, with an annotated checklist of species of Epistylis reported as epibionts of cyclopoid copepods and resources for their identification. Zootaxa, 3: 525-540.

Cruz, R.T, 1997. Case Study III - The Pasig River, Philippines In: Helmer, R. and I. Hespanhol, (eds.). Water Pollution Control - A Guide to the Use of Water Quality Management Principles. F \& FN Spon, London. no pagination.

Dorak, Z, 2013. Zooplankton abundance in the lower Sakarya River Basin (Turkey): Impact of environmental variables. Journal of the Black Sea/Mediterranean Environment, 19 (1): 1-22.

Dussart B.H. \& D. Defaye, 2001. Introduction to the Copepoda (2nd ed.). Backhuys Publishers, Leiden, The Netherlands. : Backhuys Publishers. 344 pp.

Ersanli, E. \& A. Gonulol, 2003. Study on the phytoplankton and seasonal variation of Lake Simenit (Terme-Samsun, Turkey). Turkish Journal of Fisheries and Aquatic Sciences, 3(1), 29-39.

Fernandez-Leborans, G. \& M.L. Tato-Porto, 2000. A review of the species of protozoan epibionts on crustaceans. I. Peritrich ciliates. Crustaceana, 73 (6): 643-683.

Fernando, C. (ed.), 2002. A Guide to Tropical Freshwater Zooplankton-Identification, Ecology and Impact on Fisheries. Backhuys Publishers, Leiden, The Netherlands. $291 \mathrm{pp}$.

Finlay, B. \& G. Esteban, 1998. Freshwater protozoa: Biodiversity and ecological function. Biodiversity and Conservation, 7: 1163-1186. 10.1023/A:1008879616066.

Foissner, W. \& H. Berger, 1996. A user-friendly guide to the ciliates (Protozoa, Ciliophora) commonly used by hydrobiologists as bioindicators in rivers, lakes, and waste waters, with notes on their ecology. Freshwater Biology, 35: 375-482.

Green, J.D. \& R.J. Shiel, 2000. Mobiline peritrich riders on Australian calanoid copepods. Hydrobiologia, 437: 203212. https://doi.org/10.1023/A:1026567210125.

Gregori, M., G. Fernandez-Leborans, A. Roura, A.F. González \& S. Pascual, 2016. Description of a new epibiotic relationship (Suctorian-Copepoda) in NE Atlantic waters: from morphological to phylogenetic analyses. Acta Zoologica, 97: 165-176.

Hausmann, K., N. Hülsmann \& R. Radek, 2003. Protistology. E. Schweizerbart'sche Verlagsbuchhandlung, Berlin. 379 pp.

Kudo, R.R, 1939. Protozoology. C.C. Thomas, Springfield, Illinois. 689 pp. 
López, C., E. Ochoa, R. Páez \& S. Theis, 1998. Epizoans on a tropical freshwater crustacean assemblage. Marine and Freshwater Research, 49 (3): 271-276. http:// dx.doi.org/10.1071/mf96037.

Lopez, M.L.D., J.A.F. Pascual, E.S.P. Dela Paz, E.Z.C. Rizo, D.T. Tordesillas, S.K. Guinto, H.J. Dumont, A.C. Mamaril \& R.D.S. Papa, 2017. Annotated checklist and insular distribution of freshwater microcrustaceans (Copepoda: Calanoida \& Cyclopoida; Cladocera: Anomopoda and Ctenopoda) in the Philippines. Raffles Bulletin of Zoology, 65: 623-654.

Ohtsuka, S., M. Hora, T. Suzaki, M. Arikawa, G. Omura \& K. Yamada, 2004. Morphology and host-specificity of the apostome ciliate Vampyrophrya pelagica infecting pelagic copepods in the Seto Inland Sea, Japan. Marine Ecology Progress Series, 282: 129-142.

Packroff, G. \& S. Woelfl, 2000. A review on the occurrence and taxonomy of heterotrophic protists in extreme acidic environments of $\mathrm{pH}$ values $\leq 3$. Hydrobiologia, 433: 153156. 10.1023/A:1004039309694.

Pane, L., G. Bonello \& G.L. Mariottini, 2014. Epibiotic ciliates Scyphidia sp. and diatoms on Tigriopus fulvus (Copepoda: Harpacticoida) exoskeleton. Journal of Biological Research, 87 (2): 66-69.

Papa, R.D.S., H. Li, D. Tordesillas, B.P. Han \& H. Dumont, 2012. Massive invasion of Arctodiaptomus dorsalis (Copepoda, Calanoida, Diaptomidae) in Philippine lakes: A threat to Asian zooplankton biodiversity? Biological Invasions, 14 (12): 2471-2478 DOI: 10.1007/s10530-0120250-9

Petts, G.E, 1986. Water quality characteristics of regulated rivers. Progress in Physical Geography: Earth and Environment, 10: 492-516.

Prescott, G.W, 1951. Algae of the Western Great Lakes Area. W.C. Brown Co., Dubuque, Iowa. 977 pp.

Rajabunizal, K. \& R. Ramanibai, 2011. Presence of an epibiont Epistylis niagarae (Protozoa Ciliophora) on Mesocyclops aspericornis in Velachery Lake, Chennai, India. Journal of Biological Sciences, 11: 189-195.

Regali-Seleghim M.H. \& M.J.L. Godinho, 2004. Peritrich epibiont protozoans in the zooplankton of a subtropical shallow aquatic ecosystem (Monjolinho Reservoir, São Carlos, Brazil). Journal of Plankton Research, 26: 501508.

Rosowski, J.R. \& P. Kugrens, 1973. Observations on the euglenoid Colacium with special reference to the formation and morphology of attachment material. Journal of Phycology, 9: 370-383.

Roszak, D.B. \& R.R. Colwell, 1987. Survival strategies of bacteria in the natural environment. Microbial Reviews, 51: 365-379.

Taniguchi, M., W. Ventura, K. Toyota \& M. Kimura, 1999. Epibiotic microorganisms associated with microcrustaceans in overlying water of Philippine paddy fields, Soil Science and Plant Nutrition, 45 (3): 757-766.

Utz, L.R.P. \& D.W. Coats, 2005. Spatial and temporal patterns in the occurrence of peritrich ciliates as epibionts on calanoid copepods in the Chesapeake Bay, USA. Journal of Eukaryotic Microbiology, 52(3): 236-244.

Verma, P.S. \& E.L. Jordan, 1995. Invertebrate Zoology. S. Chand \& Company Ltd., New Delhi. 848 pp.

Walkusz, W. \& L. Rolbiecki, 2007. Epibionts (Paracineta) and parasites (Ellobiopsis) on copepods from Spitsbergen (Kongsfjorden area). Oceanologia, 49 (3): 369-380.

Willey, R.L., P.A. Cantrell \& S.T. Threlkeld, 1990. Epibiotic flagellates increase the susceptibility of some zooplankton to fish predation. Limnology and Oceanography, 35: 952959. 10.4319/Lo.1990.35.4.0952.s 